\title{
Belgeo
}

Revue belge de géographie

\section{Reflections on the changing nature of administrative space}

Beschouwingen over de ongestadigheid van de administratieve ruimte

\section{Max Barlow}

\section{(2) OpenEdition}

\section{Journals}

\section{Electronic version}

URL: http://journals.openedition.org/belgeo/15712

DOI: 10.4000/belgeo.15712

ISSN: 2294-9135

\section{Publisher:}

National Committee of Geography of Belgium, Société Royale Belge de Géographie

\section{Printed version}

Date of publication: 30 September 2002

Number of pages: $217-226$

ISSN: 1377-2368

\section{Electronic reference}

Max Barlow, «Reflections on the changing nature of administrative space », Belgeo [Online], 3 | 2002,

Online since 01 October 2002, connection on 25 April 2019. URL : http://journals.openedition.org/ belgeo/15712 ; DOl : 10.4000/belgeo.15712

This text was automatically generated on 25 April 2019

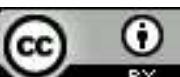

Belgeo est mis à disposition selon les termes de la licence Creative Commons Attribution 4.0 International. 


\title{
Reflections on the changing nature of administrative space
}

\author{
Beschouwingen over de ongestadigheid van de administratieve ruimte
}

\author{
Max Barlow
}

1 Over the past twenty years or so globalization has become a catch-all term for all manner of change in society, as places, people, and institutions are increasingly integrated into global structures and systems and influenced by global forces. At the same time, extension of the nation-state system to all parts of the world has been virtually completed, and thus forms a universal governmental framework within which processes of globalization are mediated. Although various global forces (notably economic) have tended to undermine and reduce the sovereignty and independence of national governments, the nation-state remains the fundamental framework within which the public sector operates and finds itself facing the challenges of a globalizing world. For the public sector, as in the corporate sector, restructuring has become a standard response, and phrases such as «rolling back the state», and «reinventing government» signify the mood of the time. The purpose of this paper is to reflect on one element of the state, administrative space, in relation to globalization and state restructuring. The paper first discusses the nature of administrative space, and then it outlines some implications arising from developments associated with globalization and state restructuring.

\section{Administrative space}

2 The term administrative space refers to the manner in which territory is organized geographically for governmental and administrative purposes: as such it is a core concept in the relationship between geography and governance. In virtually all states, including the smallest, there are subdivisions of territory for government and administration, and the need for such subdivisions is universally recognized. With increasing size the pattern of subdivision becomes more complex, as the state is subdivided in numerous ways each serving a different purpose (Fesler, 1949). The resulting territorial units include units of 
government (such as municipalities, counties, and provinces), areas of state administration, in connection with the activities of the departments and ministries of central government, and areas associated with special purpose authorities and state corporations. Each set of areas creates, in effect, a layer in the overall structure that constitutes administrative space; and the subdividing feature constitutes a horizontal dimension while the layering feature constitutes a vertical dimension.

In many respects the administrative space formed by each nation state is unique, but a common feature is that within the layers of territorial subdivisions there are strong hierarchical elements. For example departments of central government and state agencies establish administrative subdivisions at two or more levels (region and district), and levels of government are usually arranged hierarchically from local, through one or more intermediate levels, to national. Usually two broad types of hierarchy can be distinguished, the first consisting of areas created for the purpose of state administration and the second consisting of areas of self-government. In the case of the former, actions and decisions at the lower levels are integrated with and largely determined by those at higher levels, thereby creating a «spatial hierarchy of decision-making» (Leemans, 1969, p. 14), while in the case of the latter, actions and decisions at the lower levels often run counter to those at higher levels, producing complex, and often fractious, intergovernment relations. The two types of hierarchy exist concurrently, and often there is considerable overlap and interlocking, as when the state delegates tasks to units of self government and when boundaries of state administration and units of self- government coincide.

Among these hierarchies those associated with government areas are of particular significance for a number of reasons: first, they form levels around which many other elements of administrative space are structured, and their boundaries often create "containers» in relation to other territorial subdivisions; second, interactions and relationships between the levels constitute the body of central-local relations in a governmental system; third, the levels of government allow the bunching or grouping of functions so as to facilitate coordination and integration across activities and services; and fourth, the levels of government, and the government areas they contain, provide the basis for democracy and accountability in the system as a whole. This element of administrative space, government areas, is the main focus of the paper.

Within each state, government areas form a hierarchical structure in which the following characteristics occur:

- The hierarchy completely covers the territory of the state and is wholly contained by the state's international boundaries.

- Each level of the hierarchy consists of a set of space-filling and mutually exclusive areas, each of which covers a continuous and contiguous territory.

- The hierarchy is nested: every area at a lower level is wholly contained within an area at a higher level.

- The hierarchy is symmetrical; within a given level all government areas have the same responsibilities and functions.

- Intergovernmental relations occur both vertically (between levels) and horizontally (within levels).

6 When evaluating the structure of government in a state, in order to determine whether there is a need for reorganization, a number of organizing principles are usually considered, reflecting theoretical ideas concerning the form of administrative space. For 
example, the number of tiers in the hierarchy should reflect the scale needs of governance. This stems from the notion that there are several spatial scales in the organization of society, some of which require a corresponding scale of government, and from the fact that there are various scale requirements associated with government functions. The terms local, regional, and national are commonly used to relate to spatial scales in society, but they are sufficiently broad that they can mask several scale differences. Thus, for example, it is not difficult to conceptualize two scales of activity requiring local government and two or more scales of activity requiring regional government. Use of this principle can lead to a case for reorganization based on the fact that particular scale needs are not met by an existing structure.

7 Scale requirements are also important when evaluating the distribution of tasks and responsibilities among the tiers: thus, some matters may be considered «too big» for a particular level of government while others may be «too small», and when mismatches occur there is a case for reorganization. However, there are other criteria to be considered when examining the distribution of tasks among tiers: for example, some functions need to be grouped together at the same level because they are interdependent and require a degree of coordination; and it can be argued that government services where nation-wide uniformity is required should be allocated to higher tiers.

When evaluating the pattern of territorial subdivision in a given level of the hierarchy, two important principles are as follows. First, each government area should cover and contain the activity systems that relate to its functions and to the problems it is expected to deal with; and this can be described as a functional principle. Second, each government area should contain a population having a degree of shared interest and community; and this can be described as a community principle. If the functional principle is violated there can be problems related to scale economies, spillovers, and boundaries, and if the community principle is violated there can be problems related to participation and identity. Either situation can be the basis of a case for reorganization.

9 Together, these organizational principles and the characteristics described earlier can be construed as a simple model of administrative space, and whenever reorganization is being considered there are several options available within the framework of this model. These are as follows: reorganize the number of levels in the hierarchy by either creating or abolishing tiers of government; reorganize the distribution of tasks among tiers by transferring functions up or down the hierarchy; reorganize the territorial subdivision within a tier by amalgamating or breaking up government areas, or by boundary adjustments; reorganize horizontal intergovernmental relations by establishing institutional or legal frameworks within which groups of government areas can cooperate in order to function at larger geographical scale. In summary, what it comes down to is the changing of tiers, tasks, or territories.

During the second half of the twentieth century two themes were predominant in the reorganization discourse, one involving a «missing tier» problem and the other involving a «scale enlargement» problem. The first of these arose from the view that in several countries government units at an intermediate level, the so-called meso-level, were insufficient to deal with regional issues and problems, and indeed in some countries were absent. In this case, the basis of reform and reorganization was to either add a new tier of regional government or to strengthen existing regional institutions (Keating, 1997). The second problem arose from the view that the scale of local activity systems had expanded, outstripping the scale of local government units, particularly in urban areas. In this case 
the basis of reorganization was to create larger units of local government, often by means of amalgamation (Barlow, 1981). These approaches to dealing with problems arising from the structure and form of administrative space fit well with the model outlined above. Today, however, this model of administrative space, and the reorganization options that accompany it, may be less relevant: this stems from the effects of globalization and state restructuring.

\section{Globalization and state restructuring}

11 The term globalization is used to both describe and explain a multitude of changes occurring in today's world. Rooted in technological and economic change and generating political and social transformations it has been described as possibly «the concept of the 1990s, a key idea by which we understand the transition of human society into the third millennium» (Waters, 1995, p. 1, quoted in Clark, 1997, p. 16). Studies of globalization have, understandably, tended to focus on the macro scale (global economy, transnational corporations, borderless world, international organizations, and so forth) but there has also been some consideration of the micro scale, seeking to understand local impacts of, and responses to, globalization, and to establish global-local frameworks for analysis. To a considerable extent, global-local relations are mediated by the nation state and its administrative apparatus. Undoubtedly, however, globalization penetrates nation states to their structural foundations, and as a result their organizational capacity to meet its challenges is coming under increasing scrutiny; and this has given rise to state restructuring.

12 The remainder of this paper suggests ways in which administrative space is affected by four important trends related to globalization and restructuring: the development of supranational authorities and institutions; the fading influence of international boundaries; the emergence of new regional spaces; and state restructuring.

\section{Supranational authorities and institutions}

13 For much of the last century there was a trend towards the formation and development of international bodies to address global issues and to regulate the activities and behaviour of nation states. This resulted in a large number of single-purpose (for example, the International Civil Aviation Organization) and multi-purpose international organizations (for example, the Organization of American States), many of which today exist as part of the United Nations. While such organizations serve to erode the sovereignty of nation states their overall impact in this respect remains relatively small, since they are based on international agreement and consensus, they lack powers of coercion, and they are a long way from forming supranational government. However, in some parts of the world supranational government has begun to develop in connection with the process of economic integration.

Supranational economic integration occurs when two or more states seek to form a single economic unit in order to gain enhanced economic strength in the global economy. Usually the states are contiguous, and the economic unit being formed constitutes a single economic space. Customs unions and free trade associations are markers of the early stages of integration, while common markets and economic unions reflect more 
advanced stages of integration. Inevitably the process requires the states involve to relinquish elements of sovereignty in economic matters, but in its more advanced stages the process also erodes sovereignty in a wide range of policy matters. Even the relatively modest objective of a free trade association can lead to calls for a «level playing field» and «harmonization» with regard to the regulatory environment of business, and this may involve policy areas such as environmental legislation and labour legislation. Canada, in the context of integration with the United States, is a good example of this (Barlow, 2001). As economic integration deepens there develops a need for political integration and for governmental institutions at a supranational level, and in this respect the European Union (EU) represents the most advanced case of economic integration, and it contains many elements of government and administration that are normally characteristic of nation states.

The EU demonstrates how supranational institutions can develop to such an extent that a level of government is created above that of the nation state, and the implications for administrative space are considerable. Essentially a new tier of government is established, and whenever this occurs (at whatever level or scale) it affects other tiers in a number of ways. For example, while a new tier of government may be built around new tasks and activities it invariably takes on tasks previously performed by an existing tier. Also, the creation of a new tier often leads to reorganization of territories and boundaries of other tiers. In the case of adding a supranational tier of government the first of these is fairly obvious, with national governments transferring tasks to the higher level and ceding some of their sovereignty. Less obvious, but becoming apparent in the case of the $\mathrm{EU}$ is the idea that nation states begin to reorganize their administrative structures in order to conform with those of other member states: thus in some of the states there is a perceived need to strengthen regional government (for example, UK) and even in states that are yet only future members there is a perceived need to establish regional units that are comparable to those existing in member states (for example, Czech Republic).

Drawing from developments in Europe, it can be argued, hypothetically, that the overall effects of the formation of supranational institutions of government include the following: a new tier of government and administration is added to the hierarchical structure; new tasks of a transnational nature are introduced; some existing tasks are transferred up the hierarchy to the new tier; and lower tiers may undergo territorial reorganization as part of a harmonization process.

\section{Fading of international boundaries}

Globalization reduces the impact and influence of international boundaries, and it is often argued that this is leading to the creation of a borderless world. In the economic sphere, large firms have internal structures that transcend international boundaries and often ignore them, and in the political sphere nation states seek to reduce or remove some of the barrier effects of shared boundaries. The overall effect is to weaken the socalled «container» function of the state (Taylor, 1994) and to reduce the importance of boundaries as a determinant of space relations, location, and spatial interaction.

The container effect is significant in relation to administrative space because the conceptual model of administrative space assumes that the hierarchical structures involved are wholly contained within state boundaries, and that horizontal intergovernment relations are likewise bounded. As the erosion of international boundaries 
weakens the container effect it becomes increasingly possible for relations between subnational governments to stretch across international space. Whereas traditionally intergovernment relations across international boundaries have been the exclusive preserve of national governments, it is now not uncommon to find sub-national governments in different countries participating in negotiations and entering into partnership and agreements. (Duchacek, 1984; Fry et al., 1989). It is happening on a long-distance basis in connection with attracting economic investment and promoting cultural links, and on an adjacency basis in border areas to promote cooperation and coordination in a wide variety of matters.

19 In effect this introduces a new dimension in horizontal relations in administrative space, and in some instances this may be at the expense of vertical relations within the nation states involved and can be seen as a challenge to the state (Murphy, 1993). This is particularly the case in border areas, where relations with adjacent parts of neighbouring states are developed in order to compensate for a marginal situation with respect to central-local relations within the state. Another effect of these new intergovernmental relations is the fact that they serve to blur the lines of demarcation between nation-state administrative hierarchies and create a degree of interlocking of hierarchies.

\section{New regional spaces}

The need for regional government usually stems from the need for an intermediate tier of government between national and local which can deal with issues and problems that are too big for local government, but for which national government is too big. Increasingly, however, there are more specific needs for regional government arising from situations associated with globalization: these include the emergence of transborder regions, the growing economic importance of metropolitan regions, and the growth of sub-state nationalism (Barlow, 1998).

Transborder regions are, as the name suggests, regions that straddle international boundaries. They are a new kind of region because their formation is a consequence of the recent weakening of international boundaries in connection with supranational economic integration. They are most advanced within the area of the EU, but they are also emerging in other parts of Europe and in North America. For the most part these regions are motivated by economic factors and initiated by the private sector, but they also stimulate change in the public sector by creating a need for new intergovernmental relations at the local and regional levels and for new administrative structures that can facilitate spatial integration of the region and represent the region in relations with higher levels of government in the respective countries. In terms of administrative space these regions serve to blur the lines of separation between national systems and hierarchies, by creating overlapping and interlocking effects.

Metropolitan regions are not particularly new, but they are taking on new dimensions and significance in today's global economy. The concept of metropolitan region is essentially an extension of the concept of city region, denoting a region comprised of a city and its surrounding area, and metropolitan regions have often been viewed as a basis for planning and government. What is new about these regions lies in their spatial form and economic importance: the «new» metropolitan region is a multi-centred one rather than a single-centred one; its communications and traffic flows follow complex and diffuse patterns rather than conforming to a simple radial pattern; and its economic 
importance is such that it is sometimes argued that metropolitan regions are emerging as the primary units of the global economy. It has been argued that much of contemporary urbanization is «best understood not so much in terms of national urban systems, but... in terms of a worldwide mosaic of interrelated city-regions» (Scott et al., 2001, p. 57) and that such regions are «the motors of the global economy» (Scott et al., 2001, p. 15). The new importance of these regions has created renewed arguments for metropolitan government. What is envisaged, however, is different from the metropolitan government ideas of the 1960s and 1970s: it covers larger areas and has economic tasks devolved from higher levels of government. In effect, metropolitan regions are creating a niche for an intermediate tier of large areas and considerable power and strength.

\section{Sub-state nationalism}

23 Although the nation state model has now spread to virtually all parts of the world there is still a considerable lack of spatial congruence between nations and states, with the former far outnumbering the latter. The situation is one that gives rise to sub-state nationalism, which can generate cleavages and issues in the domestic politics of a state, or lead to the formation of separatist groups, or to civil wars.

Traditionally, nationalist minorities within the state have sought independence as the ultimate goal, but today it can be argued that independence may be less necessary and less relevant. In the first place, the fact that globalization is weakening nation states to the point that some have argued their demise raises the possibility that it may be pointless to strive for the creation of a new nation state. But more significantly, it can be argued that new political arrangements within existing states are a more realistic goal, and that this is made more acceptable by the fact of supranational economic integration. The EU demonstrates what can be achieved within the framework of regional government rather than through dismembering the state; and areas associated with sub-state nationalism, such as Catalonia (Spain), Flanders (Belgium), and Scotland (United Kingdom) are enjoying new visibility and power in the integrated EU, through regional institutions within existing states (Keating, 1991). Devolution and decentralization are key elements in the development of these institutions, leading not only to the transfer of tasks down the hierarchy but also to the development of asymmetrical features in the hierarchy.

\section{State restructuring}

Since the late-1980s governments everywhere have been under pressure to change their structures and modes of operation in order to reduce deficits, meet new economic challenges, and be more responsive to citizens. Previously, the need for change would usually lead to reorganization or adjustment, but in this current phase the need for change has led to a fundamental re-evaluation of the role of government and to calls for restructuring or, as it is often called, the reinventing of government. In their groundbreaking book on the subject, Osborne and Gaebler (1992) introduced several terms and concepts that have become part of the lexicon of restructuring: for example, governments are exhorted to steer rather than row, to empower rather than serve, to be competitive, to be results-oriented, and to be customer-driven. Hallmarks of restructuring include decentralization of authority and downsizing of the public sector 
through privatization, and these have set in motion a number of trends with regard to administrative space.

As privatization causes services and activities to pass from the public sector there is obviously a trend of reducing the number services and functions in government, thereby reducing the tasks associated with the various levels of government. However, among the tasks that remain in the public sector there is a growing importance of tasks involving such things as coordination, integrated planning, setting goals and standards, and monitoring performance, and a decreasing importance of tasks associated with the production and distribution of services. Less involvement directly in service provision may make government areas less susceptible to technical and spatial requirements of individual services (e.g. scale). Privatization also leads to increasing relations with private sector institutions. These include relations with institutions both within and without the government area concerned, and also relations with large transnational firms. This increases the range and scope of external relations far beyond the traditional field of intergovernmental relations, and serves to blur the lines of separation between the public and private sectors. Essentially this is part of the so-called «new» governance often proclaimed in local and urban contexts (see for example, Mayer, 1995).

With decentralization, functions and services are transferred from higher levels of government to lower levels. In terms of «reinvented» government, decentralization brings decision-making and accountability closer to citizens and communities and therefore enhances democracy and empowerment. A driving force behind decentralization is the concept of subsidiarity, which requires that services and functions should be allocated to the lowest level of government having the capacity to handle them effectively. Another factor involved in decentralization is flexibility. There may be, however, a more fundamental change under way. As government becomes more decentralized and as governments become more client-oriented and more flexible in the provision of services, it can be argued that territory becomes less important as a defining or determining factor. There is in effect a deterri-torialization of government, which results in organization that is less hierarchical, boundaries that are more fluid and less congruent, and administrative centres to be less dominant (Elkins, 1995). Such changes strike at the very core of traditional conceptions of administrative space.

\section{Conclusion}

As the twenty-first century begins, administrative space is undergoing significant changes in connection with globalization and state restructuring. What the future holds for its structure and form is far from certain, but the changes noted in this paper provide a basis for suggesting a number of trends. First, wherever the formation of governmental institutions «above» the nation state progresses to an advanced stage there will be in effect the creation of an additional tier of government and consequent redistribution of tasks among other tiers. Second, administrative space will be less circumscribed by national boundaries and intergovernmental relations among sub-national units will increasingly stretch across national boundaries: this will possibly strengthen horizontal relationships at the expense of vertical relationships and may have a flattening effect on the hierarchies of government areas. Third, hierarchies will become more asymmetrical, as different kinds of sub-national units take on different kinds of tasks and as transnational hierarchies are formed within which there are national differences in terms 
of the form and structure of administrative space. Fourth, decentralization and privatization will intensify horizontal relationships while reducing the significance of vertical bureaucratic relationships. And fifth, administrative areas and boundaries will become more flexible, more fluid, and less fixed by territoriality. These trends are most apparent in Europe, where supranationalism is most advanced and where decentralization and privatization have wrought radical state restructuring, and perhaps Europe will provide a model for the future, as far as the structure and shape of administrative space is concerned.

On a final note, it is useful to recall the notion that changes occurring at the beginning of the twentieth century constituted a world turned «upside down», as this phrase suggests the idea that changes occurring today constitute the world turning «inside out», as in many aspects of human activity space is being compressed, stretched, and reshaped in many ways. The so-called «hollowing out» of the nation state is a good example of the world being turned inside out, and many of the changes occurring in administrative space are simply part of this overall process.

\section{BIBLIOGRAPHY}

BARLOW I. M. (1991), Metropolitan Government, London, Routledge.

BARLOW I. M. (1998), «Globalisation and new regions: government and public administration aspects», GeoJournal, 45, 1-2, pp. 101-104.

BARLOW I. M. (2001), «Disintegration tendencies in Canada: sub-state nationalism and supranational economic integration», in DIJKINK G. and KNIPPEN-BERG H. (eds.), The Territorial Factor: Political Geography in a Globalising World, Amsterdam, Vossiuspers University of Amsterdam.

CLARK I. (1997), Globalization and Fragmentation: International Relations in the Twentieth Century, Oxford, Oxford University Press.

DUCHACEK I. (1984), «The international dimension of sub-national self-government», Publius, The Journal of Federalism, 14 (Fall), pp. 5-31.

ELKINS D. J. (1995), Beyond Sovereignty: Territory and Political Economy in the Twenty-First Century, Toronto, University of Toronto Press.

FESLER J. W. (1949), Area and Administration, Tuscaloosa, Alabama, University of Alabama Press.

KEATING M. (1991), «Regionalism, peripheral nationalism, and the state in Western Europe: a political model», Canadian Review of Studies in Nationalism, XVII, 1-2, pp. 117-129.

KEATING M. (1997), «The invention of regions: political restructuring and territorial government in Western Europe», Environment and Planning C: Government and Policy, 15, pp. 383-398.

LEEMANS A. F. (1969), «The spatial hierarchy of decision-making», Growth and Change, 1, 3, pp. 14-29. 
MAYER M. (1995), «Urban governance in the post-Fordist city», in HEALEY P., CAMERON S., DAVOUDI S., GRAHAM S. and MADANI-POUR A. (eds.), Managing Cities: The New Urban Context, Chichester, John Wiley \& Sons.

MURPHY A. (1993), «Emerging regional linkages within the European Community: challenging the dominance of the state», Tijdschrift voor Economische en Sociale Geografie, 84, 2, pp. 103-118.

OSBORNE D. and GAEBLER T. (1992), Reinventing Government: How the Entrepreneurial Spirit is Transforming the Public Sector, Reading, Mass, Addison-Wesley.

SCOTT A. J. (ed.) (2001), Global City-Region: Trends, Theory, Policy, Oxford, Oxford University Press.

TAYLOR P. J. (1994), «The state as container: territoriality in the modern world-system», Progress in Human Geography, 18, pp. 151-162.

WATERS M. (1995), Globalization, London.

\section{ABSTRACTS}

Over the past twenty years or so globalization has become a catch-all term for all manner of change in society. At the same time, extension of the nation-state system to all parts of the world has been virtually completed, and thus forms a universal governmental framework within which processes of globalization are mediated. Although various global forces have tended to undermine the independence of national governments, the nation-state remains the fundamental framework within which the public sector operates and finds itself facing the challenges of a globalizing world. For the public sector, as in the corporate sector, restructuring (rolling back the state, reinventing government) has become a standard response. This paper reflects on one element of the state, administrative space, in relation to globalization and state restructuring. It discusses the nature of administrative space, and outlines some implications arising from developments associated with globalization (the development of supranational authorities and institutions, the fading influence of international boundaries, the emergence of new regional spaces) and state restructuring.

Sinds een tweetal decennia is mondialisering of globalisering een verzamelnaam geworden voor allerlei veranderingen in de samenleving. Tezelfdertijd heeft het systeem van natiestaten zich uitgebreid over nagenoeg de gehele wereld en vormt het een universeel bestuurkundig kader waarbinnen de processen van globalisering doorwerking vinden. Ofschoon verschillende mondiale krachten de onafhankelijkheid van nationale regeringen dreigen te ondermijnen, blijft de natiestaat het fundamentele kader waarbinnen de openbare sector functioneert en geconfronteerd wordt met de uitdagingen van een globaliserende wereld. Het antwoord van zowel de openbare sector als van de zakenwereld is hervorming of herstructurering (de terugtredende staat, het heruitvinden van bestuur). Dit artikel bevat een aantal beschouwingen over één element van de staat, de administratieve ruimte, in relatie tot globalisering en hervorming van de staat. Het bespreekt de aard van de administratieve ruimte en schetst enkele gevolgen van de ontwikkelingen waarmee globalisering (de vorming van supranationale autoriteiten en instellingen, de verzwakkende invloed van internationale grenzen, het totstandkomen van nieuwe regionale ruimten) en de hervorming van de staat gepaard gaan. 
INDEX

Keywords: administrative space, globalization, state restructuring

motsclesnl administratieve ruimte, globalisering, hervorming van de staat

\section{AUTHOR}

MAX BARLOW

Department of Geography, Concordia University, Montreal H3G 1M8, Canada, imax@vax2.concordia.ca 